2010s-46

\title{
Lessons From the Latest Data on U.S. Productivity
}

\author{
Jan P.A.M. Jacobs, Simon van Norden
}

\begin{tabular}{c}
\hline Série Scientifique \\
Scientific Series
\end{tabular}

Montréal

Décembre 2010

(C) 2010 Jan P.A.M. Jacobs, Simon van Norden. Tous droits réservés. All rights reserved. Reproduction partielle permise avec citation du document source, incluant la notice $\odot$.

Short sections may be quoted without explicit permission, if full credit, including $@$ notice, is given to the source.
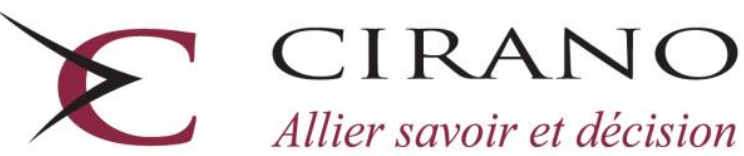

Allier savoir et décision

Centre interuniversitaire de recherche en analyse des organisations 


\section{CIRANO}

Le CIRANO est un organisme sans but lucratif constitué en vertu de la Loi des compagnies du Québec. Le financement de son infrastructure et de ses activités de recherche provient des cotisations de ses organisations-membres, d'une subvention d'infrastructure du Ministère du Développement économique et régional et de la Recherche, de même que des subventions et mandats obtenus par ses équipes de recherche.

CIRANO is a private non-profit organization incorporated under the Québec Companies Act. Its infrastructure and research activities are funded through fees paid by member organizations, an infrastructure grant from the Ministère du Développement économique et régional et de la Recherche, and grants and research mandates obtained by its research teams.

\section{Les partenaires du CIRANO}

Partenaire majeur

Ministère du Développement économique, de l'Innovation et de l'Exportation

\section{Partenaires corporatifs}

Banque de développement du Canada

Banque du Canada

Banque Laurentienne du Canada

Banque Nationale du Canada

Banque Royale du Canada

Banque Scotia

Bell Canada

BMO Groupe financier

Caisse de dépôt et placement du Québec

Fédération des caisses Desjardins du Québec

Financière Sun Life, Québec

Gaz Métro

Hydro-Québec

Industrie Canada

Investissements PSP

Ministère des Finances du Québec

Power Corporation du Canada

Raymond Chabot Grant Thornton

Rio Tinto

State Street Global Advisors

Transat A.T.

Ville de Montréal

\section{Partenaires universitaires}

École Polytechnique de Montréal

HEC Montréal

McGill University

Université Concordia

Université de Montréal

Université de Sherbrooke

Université du Québec

Université du Québec à Montréal

Université Laval

Le CIRANO collabore avec de nombreux centres et chaires de recherche universitaires dont on peut consulter la liste sur son site web.

Les cahiers de la série scientifique (CS) visent à rendre accessibles des résultats de recherche effectuée au CIRANO afin de susciter échanges et commentaires. Ces cahiers sont écrits dans le style des publications scientifiques. Les idées et les opinions émises sont sous l'unique responsabilité des auteurs et ne représentent pas nécessairement les positions du CIRANO ou de ses partenaires.

This paper presents research carried out at CIRANO and aims at encouraging discussion and comment. The observations and viewpoints expressed are the sole responsibility of the authors. They do not necessarily represent positions of CIRANO or its partners. 


\title{
Lessons From the Latest Data on U.S. Productivity
}

\author{
Jan P.A.M. Jacobs ${ }^{*}$, Simon van Norden ${ }^{*}$
}

\begin{abstract}
Résumé
La croissance de la productivité est examinée par les macro-économistes car elle joue des rôles clés dans la compréhension de l'épargne dans le secteur privé, les sources des chocs macroéconomiques, l'évolution de la compétitivité internationale et la solvabilité des régimes de retraite publics. Toutefois, les estimations des taux de croissance de la productivité anticipées et conjoncturelles souffrent de deux problèmes potentiels : (i) les estimations des tendances récentes sont imprécises, et (ii) les données récemment publiées subissent souvent d'importantes révisions.

Cette étude met en évidence la (non-) fiabilité de plusieurs mesures de croissance de la productivité agrégée aux États-Unis en examinant la mesure dans laquelle elles sont révisées au fil du temps. Nous examinons également dans quelle mesure ces révisions contribuent aux erreurs dans les prévisions de croissance de la productivité des États-Unis.

Nous constatons que les révisions de données provoquent généralement des changements appréciables des estimations des taux de croissance de la productivité publiés à travers une gamme de différentes mesures de la productivité. D'importantes révisions surviennent souvent des années après la première publication des données, ce qui contribue significativement à l'incertitude générale à laquelle nos décideurs politiques doivent faire face. Cela souligne le besoin de moyens pour réduire l'incertitude à laquelle sont confrontés les décideurs politiques et les politiques robustes à l'incertitude sur les conditions économiques actuelles.
\end{abstract}

Mots clés : Productivité, analyses en temps réel, révisions de données, projections Greenbook projections

\footnotetext{
* University of Groningen, CAMA and CIRANO.

$\dagger$ HEC Montreal, CIRANO and CIREQ. Email: Simon.van-Norden@hec.ca
} 


\begin{abstract}
Productivity growth is carefully scrutinized by macroeconomists because it plays key roles in understanding private savings behaviour, the sources of macroeconomic shocks, the evolution of international competitiveness and the solvency of public pension systems, among other things. However, estimates of recent and expected productivity growth rates suffer from two potential problems: (i) recent estimates of growth trends are imprecise, and (ii) recently published data often undergo important revisions.

This paper documents the statistical (un)reliability of several measures of aggregate productivity growth in the US by examining the extent to which they are revised over time. We also examine the extent to which such revisions contribute to errors in forecasts of US productivity growth.

We find that data revisions typically cause appreciable changes in published estimates of productivity growth rates across a range of different productivity measures. Substantial revisions often occur years after the initial data release, which we argue contributes significantly to the overall uncertainty policymakers face.

This emphasizes the need for means of reducing the uncertainty facing policymakers and policies robust to uncertainty about current economic conditions.
\end{abstract}

Keywords: Productivity, real-time analysis, data revisions, Greenbook projections

Codes JEL : C22, J24, O47 
Dec 1995 One would certainly assume that we would see this in the productivity data, but it is difficult to find it there. In my judgment there are several reasons, the most important of which is that the data are lousy.

Feb 1997 The one thing we know about the official data on productivity is that they are wrong.

Mar 1997 The productivity numbers are very rough estimates because we are measuring a whole set of production outputs from one set of data and a whole set of labor inputs from a different set. That they come out even remotely measuring actual labor productivity is open to question....

Alan Greenspan on the measurement of US productivity growth, as quoted in Anderson and Kliesen (2010) from FOMC minutes. 


\section{Introduction}

Productivity growth plays a key role in macroeconomics. Consumption and savings decisions at the core of macroeconomics depend on how perceived productivity growth trends will affect future income streams. International differences in such trends in turn have profound influences on the balance of global saving and investment. Projected productivity growth is an important factor in forecasting long-run economic growth and therefore plays a central role in the management of public pension systems and government debt. It is an essential component in forecasting measures of economic slack, and has therefore played a key role in the formulation of monetary policy. ${ }^{1}$ The possibility of a persistent change in aggregate productivity growth casts a long shadow over many of the most important international and macroeconomic policy debates. For all these reasons, great effort is devoted to accurate productivity measurement and to the timely analysis of sources of productivity growth.

But when new productivity data are published and previously published figures are revised, conclusions on the size of productivity growth can change dramatically. For example, Figure 1 shows the growth of labour productivity at four points in time (April 1974, April 1986, April 1992 and October 1996) and how these growth rates evolved over time as data were revised. ${ }^{2}$

\footnotetext{
${ }^{1}$ For example, Anderson and Kliesen (2010) carefully trace the debate over productivity growth in policy deliberations at the FOMC in the 1990s.

${ }^{2}$ Labour productivity growth is here measured by the change over 20 quarters in the natural logarithm of Output per Hour in the Private Business Sector.
} 
Figure 1: Data Revisions in US productivity growth

Business Sector: Output Per Hour of All Persons

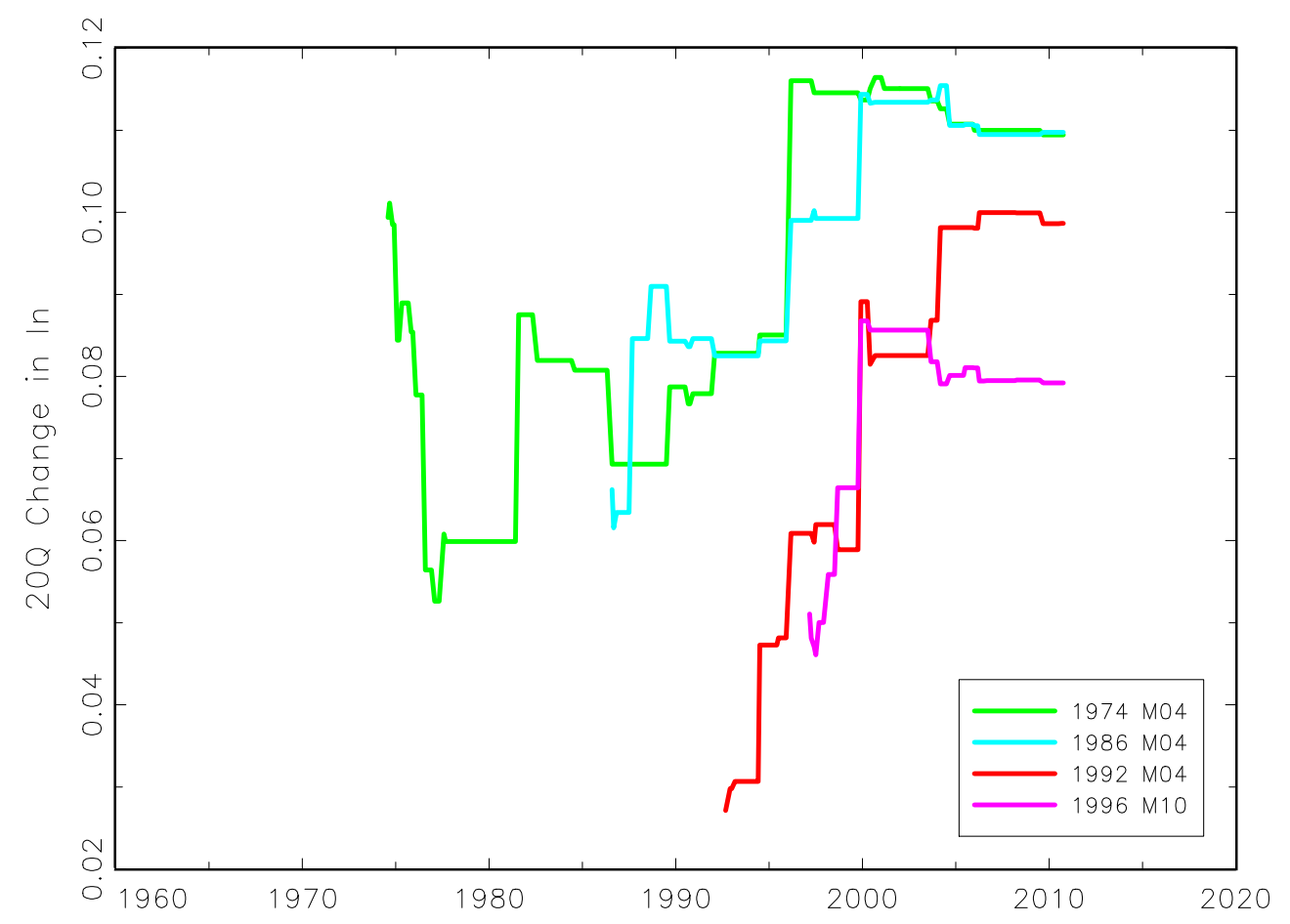

Over time, differences due to revisions become considerable, with measured productivity growth changing by a factor of two or more. As the Figure makes clear, these variations are large relative to the apparent slowdown in productivity growth over time. Some of the largest changes to our estimates for growth rate of productivity in April 1974 came more than 20 years later.

While the effects of this (and other) specific data revisions on productivity growth have previously been noted, there has been surprisingly little formal study of the systematic impact of data revision on the reliability of 
productivity growth statistics. For example, analysts studying recent productivity data would be interested to know (i) how large revisions to the latest figures may be, (ii) the expected size of any revisions, (iii) how the size of the expected revisions decreases over time, and (iv) how much time should pass before figures can be considered "reliable." We review the literature below, but little work has been done to answer such questions. Perhaps as a result, the possibility of data revisions is frequently ignored for all but the most very recent observations.

In a world with certainty equivalence, the accuracy of productivity estimates or forecasts is of little consequence; agents and policy makers react equivalently to all unbiased forecasts and estimates regardless of the uncertainty which surrounds them. However, one would expect certainty equivalence to break down in several realistic situations. For example, if households or governments face constraints on the total size of their borrowing, the probability that such constraints will bind should affect their behaviour. Similarly, prudential regulation of pension systems is most commonly concerned with limiting the probability that pension liabilities exceed pension assets. More generally, decision makers in the public and private sectors may wish to know about the distribution of future productivity growth outcomes because they have asymmetric loss functions or perhaps because they wish to weigh several related forecasts based in part on their relative reliability. In all such situations, uncertainty due to the possibility of data revisions should be of interest to economic agents and policymakers. 
It is useful to remember that, while big data revisions imply that initial estimates contained big errors, the opposite is not true; the absence of revisions does not imply that initial estimates lacked measurement error or uncertainty. For example, Jacobs and van Norden (2010b) examine data revision in simple labour productivity measures for both the USA and Italy. They find that Italian data were much less heavily revised than US data; one possible explanation for this is that more of the measurement errors in the Italian data are left uncorrected.

Some have argued that many data revisions do not reflect uncertainty or measurement errors, but simply definitional changes (e.g. due to a change in base year weights) in what is being measured. While often true in a narrow sense, this typically ignores why the definitional changes are made. Many such changes reflect the systematic efforts of statistical agencies to produce series that reflect as closely as possible the abstract concepts that statistical users have in mind. Those concepts do not undergo the same definitional changes as the statistical measures. For example, the economic concept of output that Woodford (2003) uses is not notably different from that used by Sargent (1979), although the narrow definition of the statistics used to estimate it underwent major changes in that time (e.g. from GNP to GDP and fixed-weights to chain-weighting, to name but two).

This paper documents the statistical (un)reliability of estimates of several measures of aggregate productivity in the USA. We find that data revisions are surprisingly important with a 2 to 6 percent wide 80 percent confidence 
interval for annual growth rates and noise/signal ratios typically in the range of 0.5 to 1.0. There is no particular tendency for revisions to become smaller as we restrict our attention to parts of the economy where productivity is easier to measure, such as manufacturing. The relatively important revisions in productivity series stand somewhat in contrast to the relatively smaller revisions in series used to construct productivity measures. Based on results from Federal Reserve staff economic projections, we show that these revisions also add considerable uncertainty to short-term economic forecasts.

The remainder of the paper is structured as follows. Section 2 reviews the existing literature on the reliability of estimated aggregate productivity growth trends as well as that on the properties of productivity data revisions. Section 3 discusses the characteristics of historical data revisions of different US productivity measures. Section 3.2 explains why productivity revisions are relatively much more important than the revisions in the series used to estimate productivity. Section 3.3 considers whether initial estimates of productivity growth seem to be significantly biased as well as other revision characteristics. Section 4 describes the Greenbook forecast data, and discusses the implications of data revision on Greenbook projections. Section 5 concludes. 


\section{Literature Review}

While there is an extensive applied literature on productivity measurement, it is typically based on the most recent vintage and its emphasis is on understanding the sources of productivity growth rather than assessing the statistical reliability of productivity growth rate estimates. For example, Gordon $(2000,2010)$ and Jorgenson (2001) make no attempt to compare the magnitude of the effects that they find to their statistical reliability. Jin and Jorgenson (2008), who propose and apply a latent variable approach make no mention of the precision or statistical significance of their results. The same critique applies to macroeconomic modelling exercises, such as the influential work of Smets and Wouters (2007), who ignore data revision in the estimation/calibration of their model. The studies of Field (2010) on the procyclicality of TFP in the United States over the period 1890-2004, and of Galí and van Rens (2010) on the vanishing procyclicality of in postwar US labour productivity also ignore data revision and differences in the reliability of the series that they seek to compare.

However, a few recent papers have considered the reliability of estimates of productivity growth rate trends. Edge, Laubach and Williams (2007) carefully consider the problem of estimating trend productivity growth with real-time data. They show that with such data, a heuristic linear updating rule can produce estimates of productivity growth which resemble historical estimates produced by the Council of Economic Advisors and other analysts. 
They also discuss the importance of data revisions in 1998 and late 1999 in changing estimated trend productivity growth. However, they stop short of formal statistical inference and use a stylized state-space model only as a device to justify their use of a simple updating rule.

Kahn and Rich (2007) consider the problem of detecting changes in productivity growth trends and propose a method which they find produces quick and precise detection of changes. However, their model requires several auxiliary assumptions which are difficult to justify, including:

- multiple series must undergo discrete changes in trend at the same time;

- changes in trend growth rates are temporary, although of uncertain duration;

- trend growth rates can only take on one of two possible values (a high growth or a low growth regime.)

They do not examine whether these assumptions are consistent with the data, although they provide evidence that their results are consistent across several data vintages. ${ }^{3}$

In contrast, Benati (2007) argues that the data favours models in which productivity trends vary continuously over time rather than discretely, and he provides direct tests for statistically significant changes in trend growth

\footnotetext{
${ }^{3}$ Updated results for the Kahn and Rich model published by the Federal Reserve Bank of New York in 2010 show the probabilities assigned to the high or low growth regimes may undergo substantial revisions for several years after initial estimates are published.
} 
rates. His assessment is more pessimistic, finding that univariate estimates of trends typically have wide confidence intervals and important changes in trends become apparent only after a delay of several years. ${ }^{4}$ Benati, however, does not consider the effects of data revision in his analysis.

Van Norden $(2005,2010)$ instead uses a univariate test proposed by Andrews (2003) to detect structural breaks near the end of data samples. He finds that the test requires many years of data before it is likely to detect economically important structural breaks. He also notes that repeated application of the test to US productivity growth data often produces results that vary widely over time. Some but not all of this inconsistency appears to be due to data revision.

Papers studying the revision properties of productivity growth are scarce. Aruoba (2008) analyses output per hour in the manufacturing sector and reports that revisions to annual growth rates had a standard deviation of 1.3 percent. Anderson and Kliesen (2006) provide a careful analysis of data revision across many measures of US productivity growth in the 1990s. They conclude that data revision delayed the detection of the acceleration in productivity growth in the latter half of the 1990s, but that these revisions were not unusually large by historical standards, nor were the delays in revision

\footnotetext{
${ }^{4}$ Benati (2007) concludes that "...when changes in trend productivity growth do take place, even the very best available econometric techniques may turn out to be of limited help to policymakers..." [p. 2871-72]. He also finds that estimates starting in the 1970s "...would have most likely failed to detect the productivity slowdown in real time" [p. 2870]. and that the experience in the 1990s is "....a mirror image of the productivity slowdown of the 1970s" [p. 2871].
} 
unusual. In addition to providing considerable detail on the sources of these revisions, they find that most of the revisions in output per hour worked comes from revisions to output rather than revisions to hours worked. They also examine the mean absolute revisions for a series of increasingly wellmeasured areas of the economy (e.g. moving from the business sector, to the non-farm business sector, to the manufacturing sector, to the durable manufacturing sector). They find that mean absolute revisions tend to increase as the sector is better measured, which they suggest "...likely reflects the better near-term precision with which this sector is measured, including more timely incoming revised data." ${ }^{5}$

To summarize, most of the existing literature on data revision in productivity growth has examined the closely related question of estimating and testing time-varying trend productivity growth. While Kahn and Rich (2007) are generally optimistic about the ability to detect changes in trends, even in the presence of data revision, other studies reach much more pessimistic conclusions. Anderson and Kliesen (2006) and Aruoba (2008) provide some characterizations of the revision of productivity data. Moreover, there has been no analysis of the impact of data revision on productivity growth forecasts.

\footnotetext{
${ }^{5}$ Anderson and Kliesen (2006), p. 198.
} 


\section{Measures of productivity growth}

No single measure of productivity is best for all purposes and care needs to be taken in matching the appropriate productivity measure to the problem at hand. Aggregate labour productivity, rather than aggregate or sectoral total factor productivity, is the relevant concept for many of the problems we mentioned at the outset. For consumption/savings decisions, individuals are concerned about the productivity of their labour, whether this is due to variations in total factor productivity or capital deepening. The same argument applies to studies of pension system solvency and, to some extent, to the management of public debt. ${ }^{6}$

Table 1 lists the details of our US productivity measures, including data source, span of time series available and the range of vintages studied. Our five measures include one measure of multifactor productivity (MFP) and four measures of labour productivity. MFP is also the only annual series; all the rest are quarterly. Two series cover only the manufacturing sector while the remainder are broad measures covering most or all of the economy. The output per hour measures capture data revisions from 1968 onwards while the manufacturing measures only capture revisions from the mid 1990s onwards. Note that, as of October 2010, the most recent observation for

\footnotetext{
${ }^{6}$ Consider the simple case of a government which can tax labour or capital. In an open economy, the ability to tax capital may be highly constrained by its high degree of international mobility, forcing governments to rely at the margin on labour taxes to manage their debts. The growth rate of the tax base will then be a function of labour productivity rather than total factor productivity.
} 
Table 1: Measures of US productivity growth: data

\begin{tabular}{lllll} 
Measure & Sector & Source & First/Last Period & First/Last Vintage \\
\hline GDP per Employee & All & PHIL FRB (GDP) & 19981Q1-2009Q2 & 1991Q4-2009Q3 \\
& & ALFRED (empl.) & & \\
Output Per Hour & Business & ALFRED & 1947Q1-2010Q2 & 1968M5-2010M9 \\
Output Per Hour & Non-Farm Business & ALFRED & 1947Q1-2010Q2 & 1968M5-2010M9 \\
Output Per Hour & Manufacturing & ALFRED & 1949Q1-2010Q2 & 1997M3-2010M9 \\
Multifactor Productivity & Manufacturing & ALFRED & 1949-2007 & 1996M1-2010M2 \\
\hline
\end{tabular}

Sources:

PHL FRB refers to the Philadelphia Federal Reserve Bank's Real-Time Data Set for Macroeconomists; $A L F R E D$ refers to the Federal Reserve Bank of St. Louis Alfred data base;

multifactor productivity is the 2007 figure, which makes this measure less suited for practical policy analysis and forecasting.

Figure 2 and 3 show first releases and total revisions for annual growth rates and 5-year growth rates for our five productivity measures, respectively. The similarity between output per hour of the private business sector and the non-farm business sector, the middle panel of both figures, reflects the similarity in their coverage.

\subsection{Descriptive statistics}

Data revisions may be conveniently classed into three types:

1. initial revisions in the first few vintages,

2. seasonal revisions due to updated seasonal factors and the confrontation of quarterly with annual information, and

3. benchmark or comprehensive revisions, related to changes in statistical methodology etc. 
Figure 2: First releases (solid blue line) and total revisions (thick solid red line) in annual US productivity growth
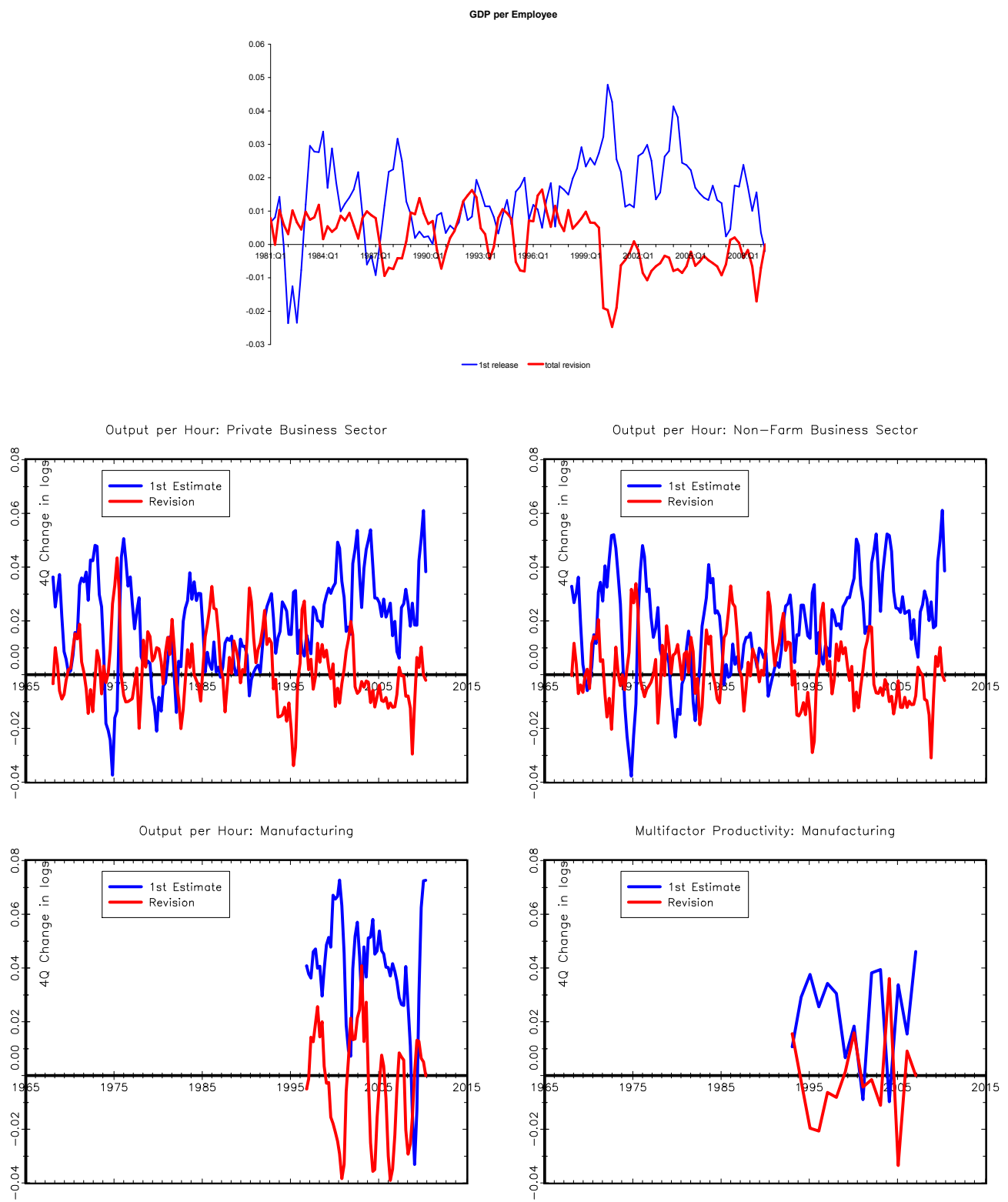
Figure 3: First releases (solid blue line) and total revisions (thick solid red line) in 5-year US productivity growth
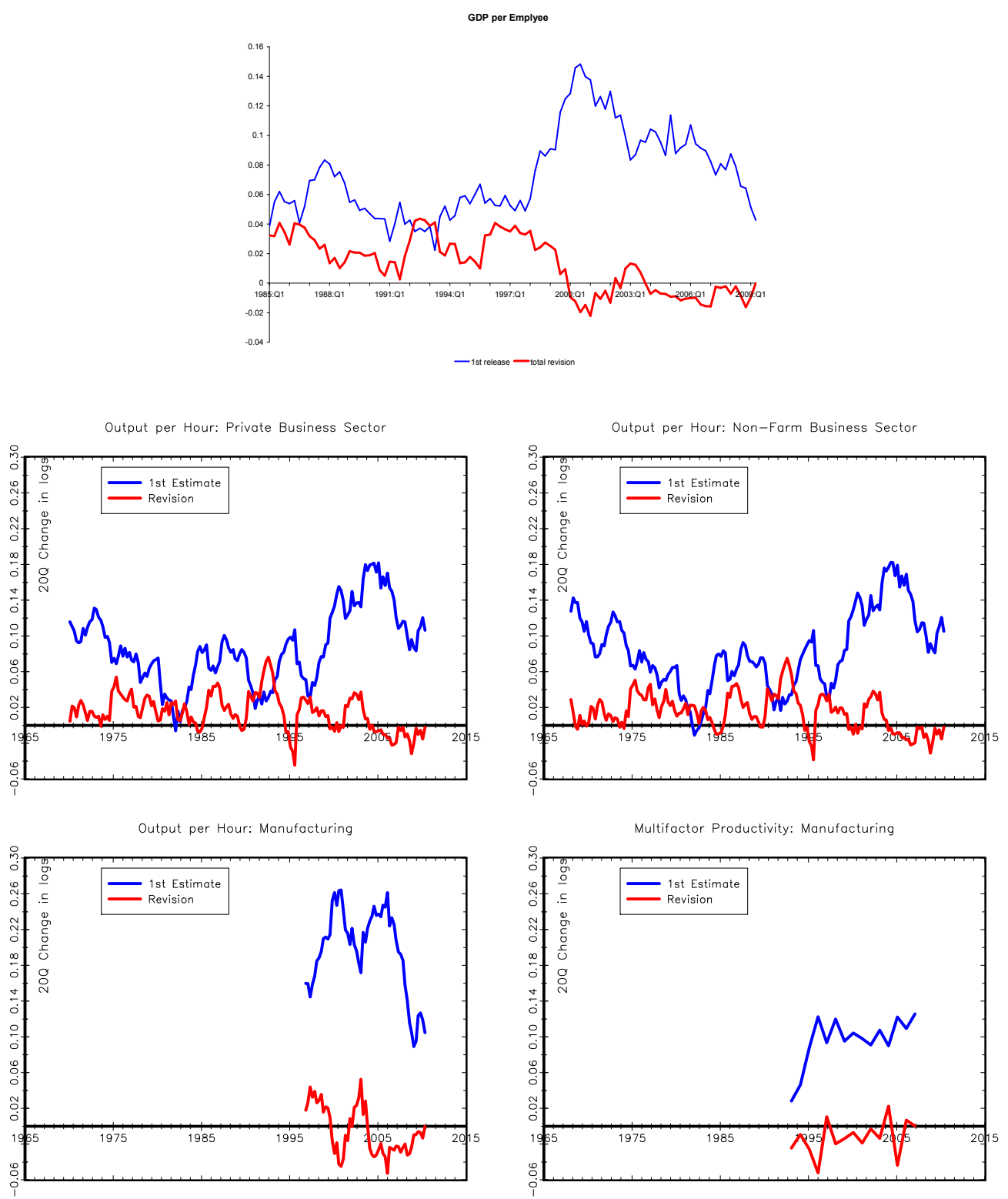
Initial and seasonal revisions are regular and recurring, i.e. can in principle be modelled and forecast. Benchmark revisions are much more difficult to handle. Redefinitions like changes of base years do not cause much difficulties, however methodological changes are much more difficult to handle. The distinction of revisions into these types requires careful handling of the realtime data and in many cases direct access to the officials of the statistical agency. We use a less rigorous approach here. We do not adjust the real-time data for benchmark revision and look at different revision periods.

Tables 2 and 3 show descriptive statistics for cumulative productivity growth rates over 4 and 20 quarters respectively for different revision periods. In addition to showing the mean growth rate based on the current data vintage $(\mathrm{CV})$ as listed in Table 1, the tables show the mean revision, the standard deviation of revisions, their extreme values, the $80 \%$ confidence interval, i.e. the revision 10th and the 90th percentile, and their noise to signal ratio $(\mathrm{N} / \mathrm{S})$ :

$$
N / S \equiv \frac{\sqrt{\left(T^{-1} \cdot \sum_{t} r_{t}^{2}\right)}}{\widehat{\sigma}}
$$

where $r_{t}$ is the revision in the published estimate for period $t$ and $\widehat{\sigma}$ is the standard deviation of the current vintage of the published series. Note that the numerator is generally greater than the standard deviation of revisions because the former will include any non-zero mean in the revisions. Revisions are defined as

$$
r_{t}^{\tau 1, \tau 2} \equiv x_{t}^{\tau 2}-x_{t}^{\tau 1}
$$


where $t$ indicates the time period for which $x$ is estimated and $\tau 1$ and $\tau 2$ indicate the periods at which the estimates were published. The upper panel of each table analyses total revisions $\left(\left\{r_{t}^{t+1, T}\right\}\right.$ for $\left.t=1, \ldots T-1\right)$. The subsequent panels provide additional detail on the behaviour of revisions over time, analysing the revisions that occur in the first year after the initial release $\left(\left\{r_{t}^{t+1, t+5}\right\}\right)$, one to five years after the initial release $\left(\left\{r_{t}^{t+5, t+21}\right\}\right)$ more than five years after the initial release $\left(\left\{r_{t}^{t+21, T}\right\}\right)$.

Looking first at Table 2, we observe that mean revisions in all measures are always much less than $1 \%$ per year and often close to $0.1 \%$. Revisions, however, have a wide range, with minimum and maximum revisions usually lying in the range of $-3.0 \%$ to $4.0 \%, 80 \%$ confidence intervals rise from just under $2 \%$ for GDP per employee to roughly $3 \%$ for broad measures of output per hour and over $5 \%$ for output per hour in manufacturing. These ranges are potentially large when compared to movements in annual productivity growth; the revisions also give noise to signal (N/S) ratios between 0.7 and 1.1. While revisions made in the first year following the initial release are not particularly small for any of the five series, in most cases they contribute relatively less of the overall uncertainty than revisions which come later. 
Table 2: Measures of annual US productivity growth: descriptive statistics

\begin{tabular}{|c|c|c|c|c|c|c|c|}
\hline & $\begin{array}{c}\text { CV } \\
\text { Mean }\end{array}$ & Mean & St. dev. & $\begin{array}{l}\text { Revisions } \\
\text { Min }\end{array}$ & Max & $80 \%$-interval & $\begin{array}{l}\mathrm{N} / \mathrm{S} \\
\text { ratio }\end{array}$ \\
\hline \multicolumn{8}{|c|}{ Labour Productivity: Output / Employment } \\
\hline Total Revisions & 0.017 & 0.000 & 0.009 & -0.024 & 0.016 & $-0.009-0.010$ & 0.95 \\
\hline 1st Yr Revisions & 0.017 & -0.001 & 005 & -0.015 & 0.009 & $-0.008-0.005$ & 0.52 \\
\hline 1st to 5th Yr Revisions & 0.017 & -0.001 & 008 & -0.023 & 0.012 & $-0.010-$ & 0.87 \\
\hline$>$ 1st Yr Revisions & 0.017 & 0.000 & 0.007 & -0.022 & 0.014 & $-0.009-0.010$ & 0.79 \\
\hline$>5$ th Yr Revisions & 0.017 & 0.002 & 0.003 & -0.002 & 0.009 & $-0.001-0.007$ & 0.41 \\
\hline \multicolumn{8}{|c|}{ Business Sector: Output Per Hour of All Persons } \\
\hline Total Revisions & 0.021 & 0.002 & 0.013 & -0.034 & 0.043 & -0.0 & 0.76 \\
\hline 1st Yr Revisions & 0.021 & 0.000 & 8 & -0.0 & 0.031 & 07 & 0.46 \\
\hline 1st to 5th Yr Revisions & 0.021 & -0.001 & 0.008 & -0.022 & 0.022 & .010 & 0.51 \\
\hline$>1$ st Yr Revisions & 0.021 & 0.002 & 0.011 & $-0 .($ & 0.034 & 015 & 0.64 \\
\hline$>5$ th Yr Revisions & 0.021 & 0.004 & 0.008 & -0.018 & 0.030 & & 0.53 \\
\hline \multicolumn{8}{|c|}{ Nonfarm Business Sector: Output Per Hour of All Persons } \\
\hline Total Revisions & 0.020 & 0.002 & 0.012 & -0.031 & 0.034 & -0 . & 0.71 \\
\hline 1st Yr Revisions & 0.020 & 0.000 & 7 & $-0 .($ & 0.026 & -0 & 0.43 \\
\hline 1st to 5th Yr Revisions & 0.020 & -0.002 & 09 & -0.022 & 0.021 & 011 & 0.51 \\
\hline$>1$ st Yr Revisions & 0.020 & 0.002 & 1 & -0 & 0.031 & -0 & 0.63 \\
\hline$>5$ st Yr Revisions & 0.020 & 0.005 & 0.008 & -0 & 0.030 & $-0.005-0.014$ & 0.53 \\
\hline \multicolumn{8}{|c|}{ Manufacturing Sector: Output Per Hour of All Persons } \\
\hline Total Revisions & 0.037 & -0.003 & 0.020 & -0 & 0.041 & -0 & 0.78 \\
\hline 1st Yr Revisions & 0.037 & 0.002 & 9 & -0.023 & 0.023 & 13 & 0.34 \\
\hline 1st to 5th Yr Revisions & 0.037 & -0.005 & 0.017 & -0.036 & 0.019 & $-0.030-0.016$ & 0.66 \\
\hline$>$ 1st Yr Revisions & 0.037 & -0.006 & 0.017 & -0.037 & 0.018 & & 0.70 \\
\hline$>5$ th Yr Revisions & 0.037 & 0.002 & 0.007 & -0.012 & 0.020 & $-0.005-0.012$ & 0.27 \\
\hline \multicolumn{8}{|c|}{ Manufacturing - Multifactor Productivity } \\
\hline Total Revisions & 0.021 & -0.002 & 017 & -0.034 & 0.036 & $-0.027-0.016$ & 1.07 \\
\hline 1st Yr Revisions & 0.021 & 0.001 & 0.017 & -0.030 & 0.047 & $-0.022-0.014$ & 1.07 \\
\hline 1st to 5th Yr Revisions & 0.021 & -0.004 & 0.010 & -0.019 & 0.017 & & 0.66 \\
\hline$>$ 1st Yr Revisions & 0.021 & -0.004 & 0.011 & -0.021 & 0.016 & $-0.020-0.013$ & 0.75 \\
\hline$>5$ th Yr Revisions & 0.021 & -0.001 & 0.011 & -0.020 & 0.022 & & 0.66 \\
\hline
\end{tabular}

Notes: CV stands for current vintage. The $80 \%$ interval gives the values for the 10th and the 90 th percentiles. The N/S ratio is the noise to signal ratio as defined in Equation (1). 
Table 3: Measures of long-run (5 yr) US productivity growth: descriptive statistics

\begin{tabular}{|c|c|c|c|c|c|c|c|}
\hline & $\begin{array}{c}\mathrm{CV} \\
\text { Mean }\end{array}$ & Mean & St. dev. & $\begin{array}{l}\text { Revisions } \\
\text { Min }\end{array}$ & Max & $80 \%$-interval & $\begin{array}{l}\mathrm{N} / \mathrm{S} \\
\text { ratio } \\
\end{array}$ \\
\hline \multicolumn{8}{|c|}{ Labour Productivity: Output / Employment } \\
\hline Total Revisions & 0.085 & 0.009 & 0.018 & -0.020 & 0.041 & $-0.012-0.035$ & 1.02 \\
\hline 1st Yr Revisions & 0.085 & -0.002 & 011 & -0.028 & 0.023 & $-0.017-0.014$ & 0.57 \\
\hline 1st to 5th Yr Revisions & 0.085 & 0.004 & 14 & -0.020 & 0.029 & $-0.015-$ & 0.74 \\
\hline 1st Yr Revisions & 0.085 & 0.012 & 13 & -0.014 & 0.039 & $-0.004-0.032$ & 0.90 \\
\hline$>5$ th Yr Revisions & 0.085 & 0.012 & 09 & -0 & 0.032 & & 0.76 \\
\hline \multicolumn{8}{|c|}{ Business Sector: Output Per Hour of All Persons } \\
\hline Total Revisions & 0.101 & 0.014 & 0.020 & -0.045 & 0.076 & -0.0 & 0.69 \\
\hline 1st Yr Revisions & 0.101 & -0.001 & 12 & -0.054 & 0.027 & -0 . & 0.32 \\
\hline 1st to 5th Yr Revisions & 0.101 & -0.002 & & $-0 .($ & 42 & & 0.45 \\
\hline$>$ 1st Yr Revisions & 0.101 & 0.016 & 8 & -0 & 75 & & 0.66 \\
\hline$>5$ th Yr Revisions & 0.101 & 0.021 & 0.016 & -0.022 & 0.066 & -0.040 & 0.73 \\
\hline \multicolumn{8}{|c|}{ Nonfarm Business Sector: Output Per Hour of All Persons } \\
\hline Total Revisions & 0.098 & 0.014 & 0.020 & -0 . & 5 & & 0.68 \\
\hline 1st Yr Revisions & 0.098 & -0.001 & & -0.0 & & & 0.32 \\
\hline 1st to 5th Yr Revisions & 0.098 & -0.003 & & -0 . & 40 & & 0.47 \\
\hline$>1$ st Yr Revisions & 0.098 & & & & & & 0.66 \\
\hline$>5$ th Yr Revisions & 0.098 & 0.022 & 0.011 & -0 & 0.068 & 042 & 0.75 \\
\hline \multicolumn{8}{|c|}{ Manufacturing Sector: Output Per Hour of All Persons } \\
\hline Total Revisions & 0.190 & -0.006 & 0.027 & -0.053 & 0.052 & -0 . & 0.59 \\
\hline 1st Yr Revisions & 0.190 & -0.002 & & -0. & & & 0.43 \\
\hline 1st to 5th Yr Revisions & 0.190 & -0.016 & & & 31 & & 0.62 \\
\hline$>$ 1st Yr Revisions & 0.190 & -0.004 & & -0.040 & 0.030 & & 0.43 \\
\hline$>5$ th Yr Revisions & 0.190 & 0.017 & 0.017 & -0.003 & 0.044 & $-0.001-$ & 0.52 \\
\hline \multicolumn{8}{|c|}{ Manufacturing - Multifactor Productivity } \\
\hline Total Revisions & 0.083 & -0.013 & & -0.052 & 0.022 & & 0.74 \\
\hline 1st Yr Revisions & 0.083 & -0.002 & & -0.042 & 0.034 & $-0.030-0.014$ & 0.52 \\
\hline 1st to 5th Yr Revisi & 0.083 & -0.014 & 0.014 & -0.037 & 0.004 & & 0.63 \\
\hline$>1$ st Yr Revisions & 0.083 & -0.012 & & & 0.008 & $-0.042-0.004$ & 0.62 \\
\hline$>5$ th Yr Revisions & 0.083 & -0.003 & 0.013 & -0.030 & 0.013 & & 0.40 \\
\hline
\end{tabular}

Notes: CV stands for current vintage. The $80 \%$ interval gives the values for the 10th and the 90th percentiles. The N/S ratio is the noise to signal ratio as defined in Equation (1). 
One could hope that revisions might be relatively less important if we looked at productivity growth over a longer period. Table 3 provides results comparable to those just discussed for growth in productivity measured over five years (20 quarters) rather than one. While results for individual series vary, overall, we have similar results. While mean revisions are comparatively small, their variability (measured by their standard deviation, or $80 \%$ confidence interval, or range, or $\mathrm{N} / \mathrm{S}$ ) is not. Again, important revisions continue to arrive long after the initial data release.

\subsection{Decomposition of noise/signal ratios}

Productivity growth can be decomposed in several ways. Corrado and Slifman (1999) for example decompose aggregate productivity growth by sector. Here we decompose the noise/signal ratios of revisions in productivity growth in terms of the behaviour of the series used to calculate productivity. Defining $\phi \equiv N / S$ and $R_{t}^{Z}$ as the revision in variable $Z$ at time $t$, we have

$$
\phi^{2} \equiv \sum_{t}\left(R_{t}^{Z}\right)^{2} / \sum_{t}\left(Z_{t}-\bar{Z}\right)^{2}
$$


where $\bar{Z} \equiv E(Z)$. Now suppose $Z_{t} \equiv Y_{t}-L_{t}$. Then we have

$$
\begin{aligned}
\phi^{2}= & \sum_{t}\left(R_{t}^{Y}-R_{t}^{L}\right)^{2} / \sum_{t}\left(Z_{t}-\bar{Z}\right)^{2}=\frac{\sum_{t}\left(\left(R_{t}^{Y}\right)^{2}+\left(R_{t}^{L}\right)^{2}-2 \cdot R_{t}^{Y} \cdot R_{t}^{L}\right)}{\sum_{t}\left(Z_{t}-\bar{Z}\right)^{2}} \\
= & \frac{\sum_{t}\left(R_{t}^{Y}\right)^{2}}{\sum_{t}\left(Z_{t}-\bar{Z}\right)^{2}}+\frac{\sum_{t}\left(R_{t}^{L}\right)^{2}}{\sum_{t}\left(Z_{t}-\bar{Z}\right)^{2}}-2 \frac{\sum_{t} R_{t}^{Y} R_{t}^{L}}{\sum_{t}\left(Z_{t}-\bar{Z}\right)^{2}} \\
= & \frac{\sum_{t}\left(R_{t}^{Y}\right)^{2}}{\sum_{t}\left(Y_{t}-\bar{Y}\right)^{2}} \cdot \frac{\sum_{t}\left(Y_{t}-\bar{Y}\right)^{2}}{\sum_{t}\left(Z_{t}-\bar{Z}\right)^{2}}+\frac{\sum_{t}\left(R_{t}^{L}\right)^{2}}{\sum_{t}\left(L_{t}-\bar{L}\right)^{2}} \cdot \frac{\sum_{t}\left(L_{t}-\bar{L}\right)^{2}}{\sum_{t}\left(Z_{t}-\bar{Z}\right)^{2}} \\
& -2 \cdot \frac{\sum_{t} R_{t}^{Y} \cdot R_{t}^{L}}{\sum_{t}\left(Y_{t}-\bar{Y}\right) \cdot\left(L_{t}-\bar{L}\right)} \cdot \frac{\sum_{t}\left(Y_{t}-\bar{Y}\right) \cdot\left(L_{t}-\bar{L}\right)}{\sum_{t}\left(Z_{t}-\bar{Z}\right)^{2}}
\end{aligned}
$$

This last equation relates $\phi^{2}$, the squared noise-signal ratio for $Z$, to the (squared) noise-signal ratio for its components $Y$ and $L$, as well as a covariance term in their revisions. When revisions to $Y$ and $L$ both have mean zero and are uncorrelated (so that $\sum_{t} R_{t}^{Y} \cdot R_{t}^{L}=0$ ), then $\phi^{2}$ is the just weighted average of the squared noise-signal ratios of the two components, where the weights are the ratios of their variances to that of $Z$. In the general case, we have an additional term that depends on both the relative importance of the covariance of $Y$ and $L$ to the overall variance of $Z$, and the cross-moment of their revisions $\left(\sum_{t} R_{t}^{Y} \cdot R_{t}^{L}\right)$.

Table 4 shows the noise/signal decomposition for annual labour productivity growth in the US. The first point to note is that while $\phi^{2}$ for labour productivity $(Z)$ is close to one, that for each of its components the noise/signal is less than $20 \%$ and that the cross-moment of their revisions is smaller still. The reason that revisions in labour productivity growth are 
relatively much more important than those in either output growth $(Y)$ or employment growth $(L)$ is simply that productivity growth is much less variable than either of its components. The results in the table also imply that revisions in output growth are the dominant contributor to revisions in labour productivity; in the absence of revisions to employment growth $\left(R_{t}^{L}=0\right), \phi^{2}$ would be equal to $0.19 \cdot 3.40=0.65$.

Table 4: Decomposing noise/signal ratios: annual labour productivity growth output / employment
(A) $\frac{\sum_{t}\left(R_{t}^{Y}\right)^{2}}{\sum_{t}\left(Y_{t}-\bar{Y}\right)^{2}}$
(B) $\frac{\sum_{t}\left(Y_{t}-\bar{Y}\right)^{2}}{\sum_{t}\left(Z_{t}-\bar{Z}\right)^{2}}$
(C) $\frac{\sum_{t}\left(R_{t}^{L}\right)^{2}}{\sum_{t}\left(L_{t}-\bar{L}\right)^{2}}$
(D) $\frac{\sum_{t}\left(L_{t}-\bar{L}\right)^{2}}{\sum_{t}\left(Z_{t}-\bar{Z}\right)^{2}}$
1.68
(E) $\quad-2 \cdot \frac{\sum_{t} R_{t}^{Y} \cdot R_{t}^{L}}{\sum_{t}\left(Y_{t}-\bar{Y}\right) \cdot\left(L_{t}-\bar{L}\right)} \quad 0.07$
(F) $\frac{\sum_{t}\left(Y_{t}-\bar{Y}\right) \cdot\left(L_{t}-\bar{L}\right)}{\sum_{t}\left(Z_{t}-\bar{Z}\right)^{2}} \quad 2.04$
(A) $\cdot(\mathrm{B})+(\mathrm{C}) \cdot(\mathrm{D})+(\mathrm{E}) \cdot(\mathrm{F}) \quad 0.94$

Another way to understand these results is to use a slightly different decomposition. Defining $\sigma_{x}^{2} \equiv T^{-1} \cdot \sum_{t}\left(x_{t}-\bar{x}\right)^{2}$ and $s_{x}^{2} \equiv T^{-1} \cdot \sum_{t}\left(R_{t}^{x}\right)^{2}$, 
the definition of $\boldsymbol{Z}$ then gives us

$$
\begin{aligned}
\sigma_{Z}^{2} & =\sigma_{Y}^{2}+\sigma_{L}^{2}-2 \cdot T^{-1} \cdot \sum_{t}\left(Y_{t}-\bar{Y}\right) \cdot\left(L_{t}-\bar{L}\right) \\
s_{Z}^{2} & =s_{Y}^{2}+s_{L}^{2}-2 \cdot T^{-1} \cdot \sum_{t} R_{t}^{Y} \cdot R_{t}^{L} \\
\therefore \phi_{Z}^{2} & =\frac{s_{Y}^{2}+s_{L}^{2}-2 \cdot T^{-1} \cdot \sum_{t} R_{t}^{Y} \cdot R_{t}^{L}}{\sigma_{Y}^{2}+\sigma_{L}^{2}-2 \cdot T^{-1} \cdot \sum_{t}\left(Y_{t}-\bar{Y}\right) \cdot\left(L_{t}-\bar{L}\right)} .
\end{aligned}
$$

Using

$$
\begin{aligned}
& \rho_{Y L} \equiv\left(T \cdot \sigma_{Y} \cdot \sigma_{L}\right)^{-1} \cdot \sum_{t}\left(Y_{t}-\bar{Y}\right) \cdot\left(L_{t}-\bar{L}\right) \quad \text { and } \\
& \gamma_{Y L} \equiv\left(T \cdot s_{Y} \cdot s_{L}\right)^{-1} \cdot \sum_{t} R_{t}^{Y} \cdot R_{t}^{L}
\end{aligned}
$$

we can rewrite this in the form

$$
\phi_{Z}^{2}=\frac{s_{Y}^{2}+s_{L}^{2}-2 \cdot s_{Y} \cdot s_{L} \cdot \gamma_{Y L}}{\sigma_{Y}^{2}+\sigma_{L}^{2}-2 \cdot \sigma_{Y} \cdot \sigma_{L} \cdot \rho_{Y L}} .
$$

From this last expression, we can see that

- $\mathrm{d} \phi / \mathrm{d} \gamma<0$, because revisions tend to cancel out.

- $\mathrm{d} \phi / \mathrm{d} \rho>0$, because there is less variability in the signal.

In the results we reported above for labour productivity, we interpret the increase in the noise-signal ratio as evidence that correlations in output and employment $(\rho)$ are more important than the comovements in their revisions $(\gamma)$ 
It is also straightforward to generalize the decomposition to the case where $Z$ is a linear combination of more than two variables; we provide a derivation in the appendix. Moving from labour productivity to TFP adds another possible source of revision; the capital stock. Capital stock estimates are heavily dependent on estimates of real investment, which themselves are among the most heavily revised portions of the national accounts. There appears to be a consensus that capital stock estimates are the most imprecise component of TFP estimates, but we are unaware of any systematic evidence on the size of their revisions. If TFP growth estimates are to be more reliable than labour productivity growth estimates, it must be the case that the uncertainty inherent in capital stock estimates serves to reduce the overall estimation error in the other two components. Whether this is the case remains to be seen.

\subsection{News, noise and bias}

The nature of data revisions has been much debated. ${ }^{7}$ Two polar views exist: (i) Data revisions contain news: data are optimal forecasts, so revisions are orthogonal to earlier releases and therefore revisions are not forecastable, which implies for the final release

$$
y_{t}^{C V}=y_{t}^{t+1}+\nu_{t}^{t+1}, \quad \operatorname{cov}\left(y_{t}^{t+1}, \nu_{t}^{t+1}\right)=0,
$$

\footnotetext{
${ }^{7}$ The debate is initiated by Mankiw, Runkle and Shapiro (1984) and Mankiw and Shapiro (1986). Recent contributions are Faust, Rogers and Wright (2005), Swanson and van Dijk (2006) and Aruoba (2008). More references are in Jacobs and van Norden (2010a).
} 
where $y_{t}^{C V}$ is the estimate available in the current vintage of $y$ at time $t$, and $y_{t}^{t+1}$ is the first release of $y$ at time $\mathrm{t}$ (assuming a one-period publication lag). (ii) Data revisions reduce noise: data are measured with error, so revisions are orthogonal to final data which allows revisions to be forecastable. For the total revision process this would imply

$$
y_{t}^{t+1}=y_{t}^{C V}+\epsilon_{t}^{t+1}, \quad \operatorname{cov}\left(y_{t}^{C V}, \epsilon_{t}^{t+1}\right)=0 .
$$

In this case, the Mincer-Zarnowitz (1969) test of the "noise" specification regresses the total revision $y_{t}^{C V}-y_{t}^{t+1}$ on a constant and the final release. More generally, we can write

$$
y_{t}^{C V}-y_{t}^{t+1}=\alpha_{1}+\beta_{1} y_{t}^{C V}+\varepsilon_{t}^{t+i} \text {. }
$$

The null hypothesis that measurement errors are independent of true values $\left(\alpha_{1}=0, \beta_{1}=0\right)$ may be tested with a Wald test; since the errors may suffer from heteroskedasticity and autocorrelation, robust standard errors are typically used.

The analogous test of the "news" model regresses the measurement error (e.g. $\left.y_{t}^{C V}-y_{t}^{t+1}\right)$ on a constant and the first release

$$
y_{t}^{C V}-y_{t}^{t+1}=\alpha_{2}+\beta_{2} y_{t}^{t+1}+u_{t}^{t+1} \text {. }
$$

The similar null hypothesis $\left(\alpha_{2}=0, \beta_{2}=0\right)$ now tests whether data revisions 
are predictable. The two null hypotheses are mutually exclusive but they are not collectively exhaustive, i.e. we may be able to reject both hypotheses, particularly when the constant in both test equations differs from zero (see Aruoba, 2008, Appendix A.2).

Table 5 and 6 list the estimation outcomes for Equations (4) and (5) for annual productivity growth and long-run (5-year) productivity growth. We observe that when testing at the $5 \%$ significance level, data revisions in annual productivity growth are neither news nor noise for labour productivity, output per hour in the business sector and the non-farm business sector, news for output in the manufacturing sector, while the news and noise null hypotheses are not rejected for multifactor productivity

In addition, test outcomes for bias are included in the tables. We report the estimate of the constant in a regression of the total revision on a constant with Newey-West HAC standard outcomes. Total revisions in annual productivity growth are not significantly biased for any US productivity measure except GDP per employee. In contrast, using 20Q growth rate revisions we find significant bias in revisions for all productivity measures except for output per hour in the manufacturing sector. 


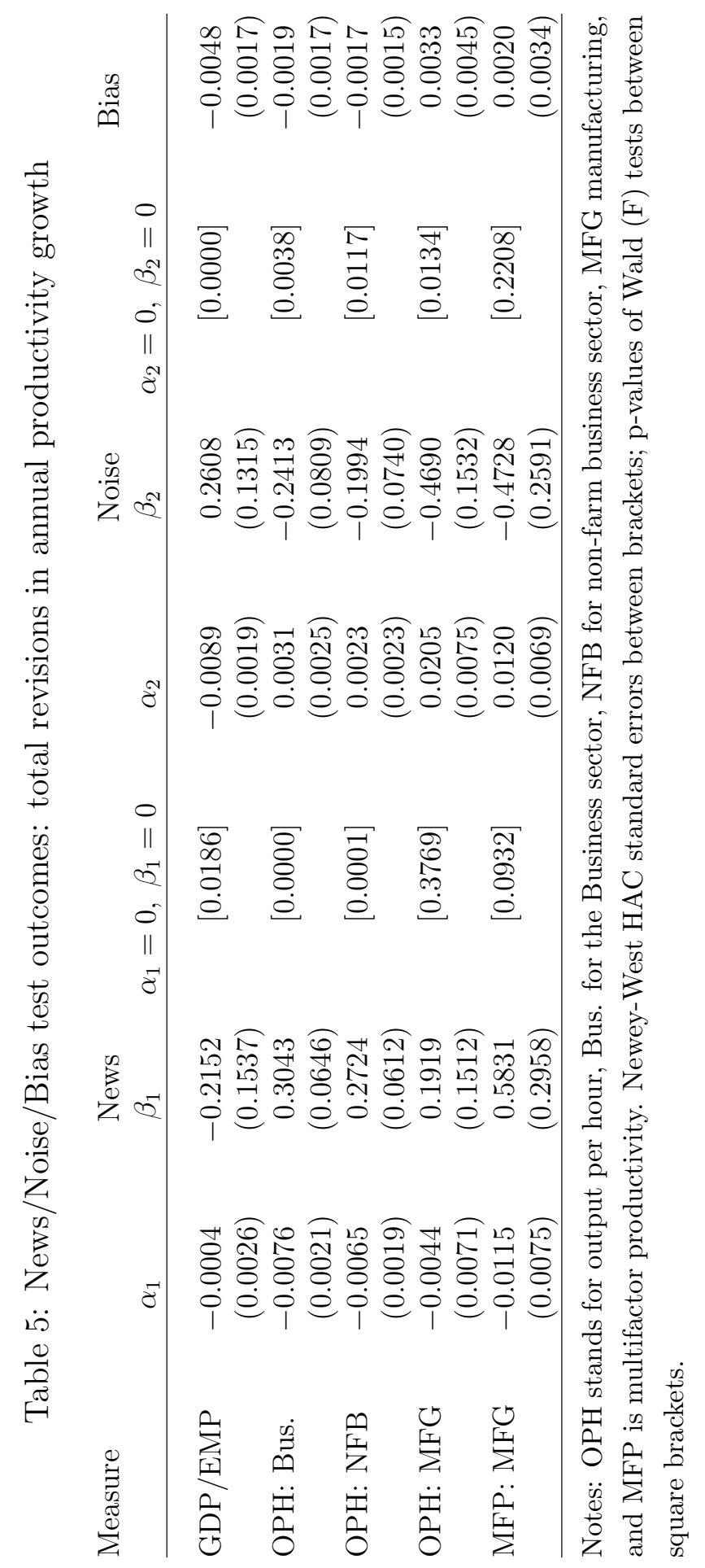




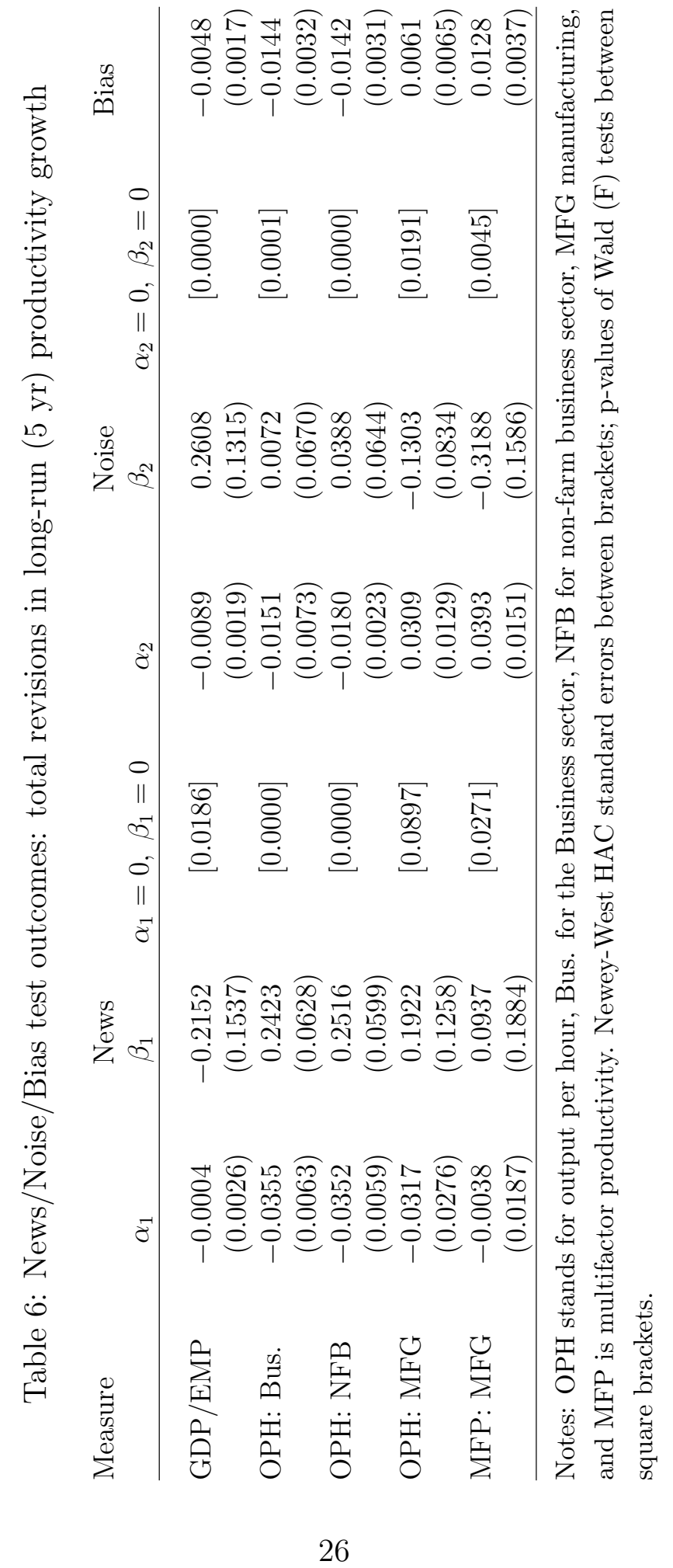




\section{Greenbook projections}

To examine the relative importance of data revisions from a policy perspective, we compare in this section the size of data revisions to the size of errors associated with productivity growth rate forecasts. The forecasts that we analyse here are those prepared by the staff of the US Federal Reserve Board for each meeting of the Federal Open Market Committee (FOMC) as part of their regular "Greenbook" projections. ${ }^{8}$ Their forecasts for growth in Output per Hour in the Non-Farm Business sector (OPH-NFB) have been tabulated and are available from the Federal Reserve Bank of St. Louis' ALFRED database.

These are forecasts for quarterly growth at annual rates from 0 to 10 quarters ahead and represent staff projections prepared for FOMC meetings from 11 January 1978 to 8 December 2004, for a total of 224 meetings. $^{9}$ The projection horizon varies over time and generally tended to increase, with the result that a full 224 forecasts are available at horizons from 0 to 4 quarters, but that thereafter the number declines to only 125 (7) at the 7 (10) quarter horizon. These forecasts cover productivity growth from 1977Q3 to 2006Q4, a period of substantial variation in productivity growth rates. As the FOMC regularly meets eight times per year, we typically

\footnotetext{
${ }^{8}$ Descriptions of Current Economic and Financial Conditions, or "The Greenbook", its contents and use may be found on the Federal Reserve Board's website at http: //www.federalreserve.gov/monetarypolicy/fomc historical.htm.

The same site also makes available archival copies of this and other FOMC briefing materials subject to a 5-year publication lag.

${ }^{9}$ See Faust and Wright (2009) for an alternative account of Greenbook forecasts.
} 
have two separate forecasts produced in each quarter. However, we make no attempt to distinguish between "early-quarter" and "late-quarter" forecasts; we would expect "early-quarter" forecasts to be somewhat less reliable and "late-quarter" forecasts to be somewhat more reliable than indicated by the results that we present below.

To assess the accuracy of these forecasts, we first convert them to the implied change in the natural logarithm of productivity over the forecast horizon. ${ }^{10}$ We then compare the forecasts to the measured change in log productivity over the same period using both the 1st-release and the currentvintage estimates of $\mathrm{OPH}-\mathrm{NFB}$. This difference should give us an indication of whether the data revisions that we have documented are small relative to the forecast errors. ${ }^{11}$ The properties of the two sets of forecast errors are summarized below in Tables 7 and 8 and Figure 4 . While we report results for all forecast horizons, due to the limited number of observations on long-horizon forecasts, we limit our discussion to forecasts horizons of 0 to 7 quarters.

\footnotetext{
${ }^{10} \mathrm{As}$ an example, consider a Greenbook forecast for productivity growth of $4,3,2$ and 1 starting with the current quarter and ending three quarters from now. These are expressed as quarter-to-quarter growth at annual rates in percent; this implies quarterly changes of $0.0100,0.0075,0.0050$ and 0.0025 in each consecutive quarter. Converting this to the cumulative change in the natural logarithm of productivity growth gives us forecast growth of $0.0100,0.0174,0.0224$ and 0.0249 .

${ }^{11}$ By comparing FOMC meeting dates with data release dates, we found many FOMC meetings where the first period marked as a "projection" by FOMC staff (i.e. our 0Q horizon forecast) was a period for which official productivity growth estimates had already been released. In such cases, however, there were typically small discrepancies between the growth rate implied by the official data series and the Greenbook projection, suggesting that the staff may have been trying to predict revisions in the official series.
} 
Table 7: Greenbook Forecast Errors (Q/Q growth rates)

\begin{tabular}{|c|c|c|c|c|c|}
\hline Horizon & Mean & St. dev. & Min & Max & \# Obs \\
\hline \multicolumn{6}{|c|}{ 1st release data } \\
\hline 0 & 0 & 0.0044 & -0.0118 & 0.0169 & 224 \\
\hline 1 & -0.0005 & 0.0055 & -0.0176 & 0.0237 & 224 \\
\hline 2 & -0.0003 & 0.0059 & -0.0216 & 0.0210 & 224 \\
\hline 3 & -0.0002 & 0.0058 & -0.0201 & 0.0212 & 224 \\
\hline 4 & -0.0003 & 0.0057 & -0.0142 & 0.0217 & 224 \\
\hline 5 & -0.0002 & 0.0060 & -0.0157 & 0.0210 & 204 \\
\hline 6 & -0.0004 & 0.0055 & -0.0132 & 0.0217 & 170 \\
\hline 7 & -0.0003 & 0.0062 & -0.0140 & 0.0229 & 125 \\
\hline 8 & -0.0015 & 0.0057 & -0.0140 & 0.0227 & 77 \\
\hline 9 & -0.0024 & 0.0046 & -0.0140 & 0.0085 & 39 \\
\hline 10 & -0.0001 & 0.0061 & -0.0095 & 0.0092 & 7 \\
\hline \multicolumn{6}{|c|}{ Current Vintage data } \\
\hline 0 & -0.0012 & 0.0062 & -0.0164 & 0.0155 & 224 \\
\hline 1 & -0.0016 & 0.0074 & -0.0212 & 0.0209 & 224 \\
\hline 2 & -0.0015 & 0.0074 & -0.0220 & 0.0153 & 224 \\
\hline 3 & -0.0013 & 0.0074 & -0.0206 & 0.0175 & 224 \\
\hline 4 & -0.0014 & 0.0071 & -0.0206 & 0.0202 & 224 \\
\hline 5 & -0.0013 & 0.0073 & -0.0213 & 0.0170 & 204 \\
\hline 6 & -0.0014 & 0.0066 & -0.0171 & 0.0160 & 170 \\
\hline 7 & -0.0015 & 0.0068 & -0.0179 & 0.0165 & 125 \\
\hline 8 & -0.0014 & 0.0071 & -0.0179 & 0.0163 & 77 \\
\hline 9 & -0.0022 & 0.0055 & -0.0179 & 0.0091 & 39 \\
\hline 10 & -0.0016 & 0.0082 & -0.0143 & 0.0099 & 7 \\
\hline
\end{tabular}


Table 8: Greenbook Forecast Errors (cumulative growth rates)

\begin{tabular}{rcrlrr} 
Horizon & Mean & St. dev. & Min & Max & \# Obs \\
\hline \multicolumn{7}{c}{ 1st release data } & & & \\
0 & 0 & 0.0044 & -0.0118 & 0.0169 & 224 \\
1 & -0.0005 & 0.0069 & -0.0201 & 0.0270 & 224 \\
2 & -0.0008 & 0.0094 & -0.0338 & 0.0289 & 224 \\
3 & -0.0010 & 0.0115 & -0.0320 & 0.0298 & 224 \\
4 & -0.0013 & 0.0137 & -0.0326 & 0.0382 & 224 \\
5 & -0.0024 & 0.0159 & -0.0338 & 0.0464 & 204 \\
6 & -0.0054 & 0.0151 & -0.0375 & 0.0416 & 170 \\
7 & -0.0074 & 0.0167 & -0.0446 & 0.0472 & 125 \\
8 & -0.0128 & 0.0165 & -0.0477 & 0.0386 & 77 \\
9 & -0.0182 & 0.0175 & -0.0489 & 0.0056 & 39 \\
10 & -0.0277 & 0.0203 & -0.0496 & 0.0113 & 7 \\
& Current Vintage & data & & & \\
0 & -0.0012 & 0.0062 & -0.0164 & 0.0155 & 224 \\
1 & -0.0027 & 0.0091 & -0.0356 & 0.0196 & 224 \\
2 & -0.0042 & 0.0126 & -0.0386 & 0.0225 & 224 \\
3 & -0.0055 & 0.0148 & -0.0487 & 0.0289 & 224 \\
4 & -0.0069 & 0.0162 & -0.0466 & 0.0344 & 224 \\
5 & -0.0086 & 0.0175 & -0.0487 & 0.0394 & 204 \\
6 & -0.0119 & 0.0174 & -0.0478 & 0.0362 & 170 \\
7 & -0.0142 & 0.0188 & -0.0508 & 0.0295 & 125 \\
8 & -0.0175 & 0.0217 & -0.0573 & 0.0242 & 77 \\
9 & -0.0219 & 0.0236 & -0.0694 & 0.0236 & 39 \\
10 & -0.0355 & 0.0260 & -0.0681 & -0.0032 & 7 \\
\hline & & & & &
\end{tabular}


Figure 4: Greenbook productivity projections, first releases and current vintage values

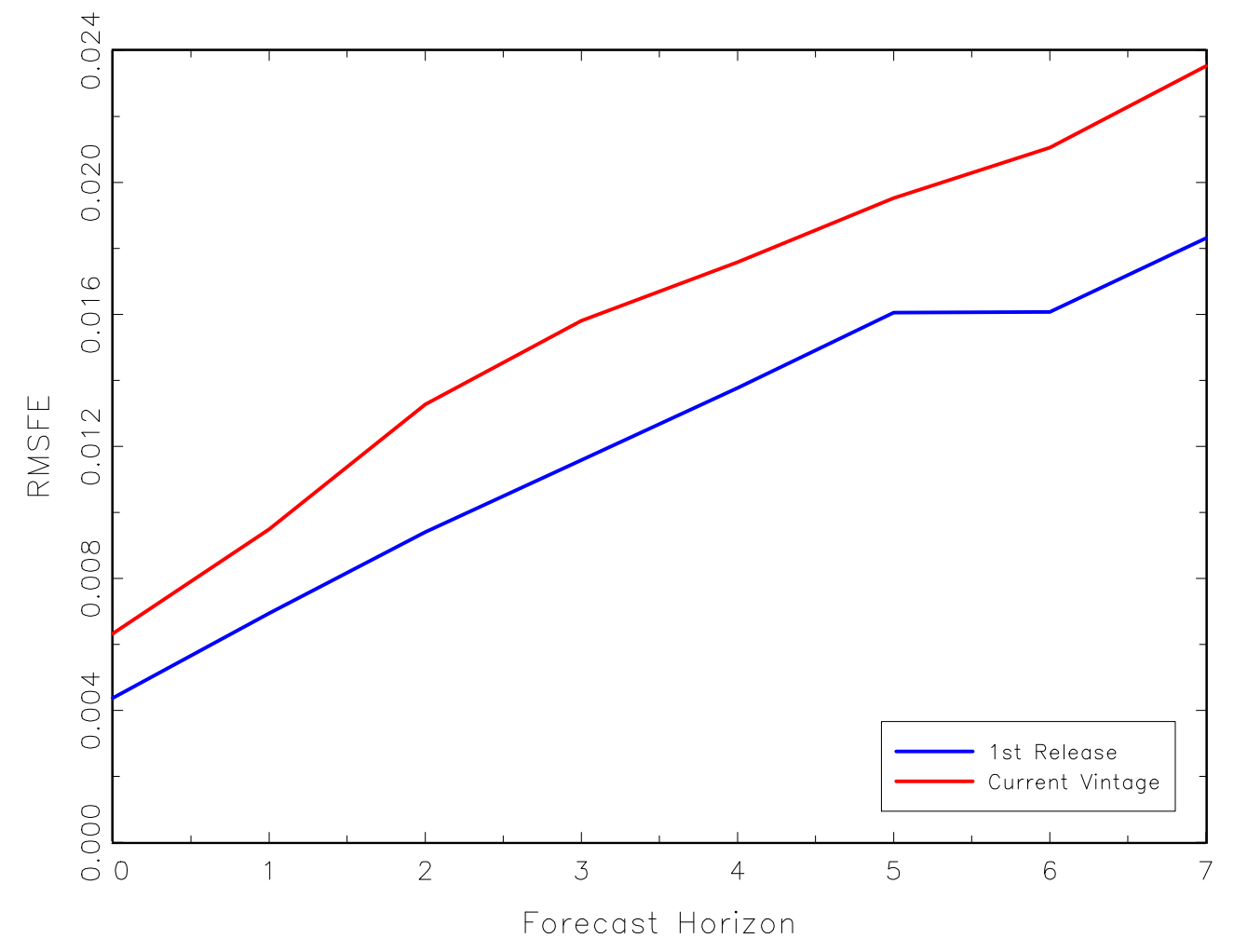

Tables 7 and 8 show some important differences in forecast errors between the two outcome measures. While the forecast errors have a negative mean at almost all horizons, the mean is considerably further from zero when using current-vintage data. The standard deviation of the forecast errors are also larger, particularly at horizons 0 to 2 where they increase by $20-40 \%$. These two effects combine when we calculate the root-mean-squared forecast error (RMSFE) which we show as a function of forecast horizon in Figure 4. The 
figure shows that data revision increases the apparent RMSFE by 20-45\% across the eight forecast horizons shown. ${ }^{12}$ We therefore conclude that data revisions appear to contribute to measured forecast errors in the Greenbook projections in an appreciable way.

\section{Conclusion}

This paper analysed the revision of several measures of aggregate productivity growth in the USA. We find that data revisions are surprisingly important with $80 \%$ confidence intervals that are larger than the mean annual growth rate of productivity and noise/signal ratios in the range of $0.5-1.0$. Revisions are important for both annual and five-year average growth rates and important revisions are made both in the first year after and long after the preliminary release. Part of the reason that the relative size of the revisions may be surprising is that they are much larger than that in either the real output or employment growth series used to calculate labour productivity growth. We provide a decomposition which shows that this is due to the fact the productivity growth has a much lower variance than either of its components. This make revisions of a given size relatively more important and highlights part of the challenge in accurate productivity measurement. Revisions are not "well-behaved" in the sense that, for most of the series

\footnotetext{
${ }^{12}$ Based on the very limited number of observations for horizons of more than 7 quarters (which also reflect the more recent Greenbook forecasts), results in Tables 7 and 8 suggest that forecast errors continue to increase with forecast horizon.
} 
we examined, they fit neither the standard "news" nor "noise" models of measurement errors. Revision errors contribute substantially to measured forecast errors at the shortest horizons and appear to increase them by $20 \%$ or more at all horizons that we examine.

Considerable revisions across a range of productivity growth measures contribute significantly to the overall uncertainty policymakers face. Reducing this uncertainty and designing policies appropriate for such uncertainty should be a major priority for economists. 


\section{Appendix}

Let $N / S \equiv \phi$ where $\phi^{2} \equiv\left(\boldsymbol{R}^{Z}\right)^{\prime} \cdot\left(\widetilde{\boldsymbol{Z}}^{\prime} \cdot \widetilde{\boldsymbol{Z}}\right)^{-1} \cdot \boldsymbol{R}^{Z}$ and where $\boldsymbol{R}^{Z}$ is the $T \times 1$ vector of revisions in each element of $\boldsymbol{Z}$, where $\boldsymbol{Z}$ is also a $T \times 1$ vector and $\widetilde{\boldsymbol{Z}}$ is the $T \times 1$ vector containing deviations of $\boldsymbol{Z}$ from its sample mean.

Now suppose $\boldsymbol{Z}=\boldsymbol{X} \cdot \boldsymbol{\omega}$ where $\boldsymbol{X}$ is an $T \times n$ matrix of variables and $\boldsymbol{\omega}$ is an unrestricted $n \times 1$ vector of weights (i.e. each element $\omega_{i}$ may lie anywhere on the real line.) $\boldsymbol{R}^{X}$ is the conformable $T \times n$ matrix of revisions associated with each element of $\boldsymbol{X}$. Therefore,

$$
\phi^{2} \equiv\left(\boldsymbol{R}^{Z}\right)^{\prime} \cdot\left(\widetilde{\boldsymbol{Z}}^{\prime} \cdot \widetilde{\boldsymbol{Z}}\right)^{-1} \cdot \boldsymbol{R}^{Z}=\boldsymbol{\omega}^{\prime} \cdot\left(\boldsymbol{R}^{X}\right)^{\prime} \cdot\left(\widetilde{\boldsymbol{Z}}^{\prime} \cdot \widetilde{\boldsymbol{Z}}\right)^{-1} \cdot \boldsymbol{R}^{\boldsymbol{X}} \cdot \boldsymbol{\omega}
$$

Assume that

1. $\left(\widetilde{\boldsymbol{X}^{\prime}} \cdot \widetilde{\boldsymbol{X}}\right)^{-1}$ exists, where $\widetilde{\boldsymbol{X}}$ is the $T \times 1$ vector containing deviations of $\boldsymbol{X}$ from its sample mean.

2. $\boldsymbol{C}$ exists, such that $\boldsymbol{C} \cdot \boldsymbol{C}^{\prime}=\left(\widetilde{\boldsymbol{X}^{\prime}} \cdot \widetilde{\boldsymbol{X}}\right)^{-1}$ and $\boldsymbol{C}^{-1}$ exist.

Therefore $\phi^{2} \equiv \boldsymbol{\omega}^{\prime} \cdot\left(\boldsymbol{R}^{X}\right)^{\prime} \cdot \boldsymbol{C}^{\prime} \cdot\left(\boldsymbol{C}^{\prime}\right)^{-1} \cdot\left(\widetilde{\boldsymbol{Z}}^{\prime} \cdot \widetilde{\boldsymbol{Z}}\right)^{-1} \cdot \boldsymbol{C}^{-1} \cdot \boldsymbol{C} \cdot \boldsymbol{R}^{X} \cdot \boldsymbol{\omega}$, or $\phi^{2} \equiv \boldsymbol{\omega}^{\prime} \cdot\left(\boldsymbol{R}^{X}\right)^{\prime} \cdot \boldsymbol{C}^{\prime} \cdot\left[\left(\boldsymbol{C}^{\prime}\right)^{-1} \cdot\left(\widetilde{\boldsymbol{Z}}^{\prime} \cdot \widetilde{\boldsymbol{Z}}\right)^{-1} \cdot \boldsymbol{C}^{-1}\right] \cdot \boldsymbol{C} \cdot \boldsymbol{R}^{X} \cdot \boldsymbol{\omega} \equiv \boldsymbol{\omega}^{\prime} \cdot \boldsymbol{A}^{\prime}$ $[\boldsymbol{B}] \cdot \boldsymbol{A} \cdot \boldsymbol{\omega}$, where $\boldsymbol{B} \equiv\left(\boldsymbol{C}^{\prime}\right)^{-1} \cdot\left(\widetilde{\boldsymbol{Z}}^{\prime} \cdot \widetilde{\boldsymbol{Z}}\right)^{-1} \cdot \boldsymbol{C}^{-1}=\left(\boldsymbol{C}^{\prime}\right)^{-1} \cdot \boldsymbol{C}^{-1} \cdot\left(\widetilde{\boldsymbol{Z}}^{\prime} \cdot \widetilde{\boldsymbol{Z}}\right)^{-1}$ (because $\widetilde{\boldsymbol{Z}}^{\prime} \cdot \widetilde{\boldsymbol{Z}}$ is a scalar $)=\left(\widetilde{\boldsymbol{X}}^{\prime} \cdot \widetilde{\boldsymbol{X}}\right) \cdot\left(\widetilde{\boldsymbol{Z}}^{\prime} \cdot \widetilde{\boldsymbol{Z}}\right)^{-1}$. This is just the scaled covariance matrix of $\boldsymbol{X}$, where variances and covariances are scaled relative to the variance of $\boldsymbol{Z} . \boldsymbol{A} \equiv \boldsymbol{C} \cdot \boldsymbol{R}^{X}$ is the matrix N/S ratio for the series $\boldsymbol{X}$. 
Note that the results are invariant to $|\boldsymbol{\omega}|$, since if we replace $\boldsymbol{\omega}$ everywhere with $\boldsymbol{\lambda} \cdot \boldsymbol{\omega}$ for any real scalar $\boldsymbol{\lambda}$, we just get $\phi^{2} \equiv \boldsymbol{\lambda} \cdot \boldsymbol{\omega}^{\prime} \cdot\left(\boldsymbol{R}^{X}\right)^{\prime} \cdot\left(\boldsymbol{\lambda} \cdot \widetilde{\boldsymbol{Z}}^{\prime} \cdot \widetilde{\boldsymbol{Z}} \cdot \boldsymbol{\lambda}\right)^{-1} \cdot \boldsymbol{R}^{X} \cdot \boldsymbol{\omega} \cdot \boldsymbol{\lambda}=\boldsymbol{\omega}^{\prime} \cdot\left(\boldsymbol{R}^{X}\right)^{\prime} \cdot\left(\widetilde{\boldsymbol{Z}}^{\prime} \cdot \widetilde{\boldsymbol{Z}}\right)^{-1} \cdot \boldsymbol{R}^{X} \cdot \boldsymbol{\omega}$. In general, $\boldsymbol{C}$ and $\widetilde{\boldsymbol{X}}$ will be trivial to calculate as they require only current vintage data. 


\section{Acknowledgements}

This paper was written during visits of the first author to CIRANO, of the second author to the research school SOM of the University of Groningen, and of both authors to the Centre of Applied Macroeconomic Analysis (CAMA), Australian National University, and the University of Tasmania (UTAS). The hospitality and support of these institutions, as well as that of CIREQ, is gratefully acknowledged. We would like to thank Robert Inklaar and Marcel Timmer of the Groningen Growth and Development Center (GGDC), and Shaun Vahey for helpful discussions and the participants of a workshop at the Federal Reserve Bank of Philadelphia, November 2009, especially Dean Croushore and Frank Diebold, for their helpful comments, as well as participants at the 2010 Joint Statistical Meetings, Vancouver, BC, August 2010, the 6th Colloquium on Modern Tools for Business Cycle Analysis: the lessons from global economic crisis, Luxembourg, September 2010, and the Finance and the Macroeconomy Workshop, CAMA, ANU, October 2010, and various seminars. 


\section{References}

Anderson, Richard G. and Kevin L. Kliesen (2006), "The 1990s acceleration in labor productivity: Causes and measurement", Federal Reserve Bank of St. Louis Review, 88(3), 181-202.

Anderson, Richard G. and Kevin L. Kliesen (2010), "FOMC learning and productivity growth (1985-2003): A reading of the record", ederal Reserve Bank of St. Louis Review, (March/April), 129-154.

Andrews, D.W.K. (2003), "End-of-sample instability tests", Econometrica, 71, 1661-1694.

Aruoba, S. Borağan (2008), "Data revisions are not well behaved", Journal of Money, Credit and Banking, 40, 319-340.

Benati, Luca (2007), "Drifts and breaks in labour productivity", Journal of Economic Dynamics and Control, 31, 2847-2877.

Corrado, Carol and Lawrence Slifman (1999), "Decomposition of productivity and unit costs", American Economic Review, 89, 328-332.

Edge, Rochelle M., Thomas Laubach, and John C. Williams (2007), "Learning and shifts in long-run productivity growth", Journal of Monetary Economics, 54, 2421-2438.

Faust, J., J.H. Rogers, and J.H. Wright (2005), "News and noise in G-7 GDP announcements", Journal of Money, Credit, and Banking, 37, 403-419. 
Faust, Jon and Jonathan H. Wright (2009), "Comparing Greenbook and reduced form forecasts using a large realtime dataset", Journal of Business E6 Economic Statistics, 27, 468-479.

Field, Alexander J. (2010), "The procyclical behavior of total factor productivity in the United States, 1890-2004", The Journal of Economic History, 70, 326-350.

Galí, Jordi and Thijs van Rens (2010), "The vanishing procyclicality of labor productivity", Discussion Paper No. 5099, IZA.

Gordon, Robert J. (2000), "Does the New Economy measure up to the great inventions of the past?", Journal of Economic Perspectives, 14, 4974.

Gordon, Robert J. (2010), "Revisiting U.S. productivity growth over the past century with a view of the future", Working Paper 15834, National Bureau of Economic Research.

Hui Jin and Dale W. Jorgenson (2008), "Econometric modeling of technical change", Mimeo.

Jacobs, Jan P.A.M and Simon van Norden (2010a), "Modeling data revisions: Measurement error and dynamics of "true" values", Journal of Econometrics [forthcoming].

Jacobs, Jan P.A.M and Simon van Norden (2010b), "What do macroeconomists know about productivity growth?", Presented at the 2010 Joint Statistical Meetings Manuscript, Vancouver, BC. 
Jorgenson, Dale W. (2001), "Information technology and the U.S. economy", American Economic Review, 90, 1-32.

Kahn, James A. and Robert W. Rich (2007), "Tracking the new economy: Using growth theory to detect changes in trend productivity", Journal of Monetary Economics, 54, 1670-1701.

Mankiw, N.G., D.E. Runkle, and M.D. Shapiro (1984), "Are preliminary announcements of the money stock rational forecasts?", Journal of Monetary Economics, 14, 15-27.

Mankiw, N.G. and M.D. Shapiro (1986), "News or noise: An analysis of GNP revisions", Survey of Current Business, 66, 20-25.

Mincer, Jacob and Victor Zarnowitz (1969), "The evaluation of economic forecasts", in Jacob Mincer, editor, Economic Forecasts and Expectations: Analyses of Forecasting Behavior and Performance, National Bureau of Economic Research, New York, chapter 1, 3-46.

Sargent, T.J. (1979), Macroeconomic theory, Academic Press, Orlando, Fla.

Smets, Frank and Rafael Wouters (2007), "Shocks and frictions in US business cycles: A Bayesian DSGE approach", American Economic Review, 97, 586-606.

Swanson, Norman R. and Dick van Dijk (2006), "Are statistical reporting agencies getting it right? Data rationality and business cycle asymmetry", Journal of Business 83 Economic Statistics, 24, 24-42. 
van Norden, Simon (2005), "Are we there yet? Looking for evidence of a New Economy", Manuscript, HEC Montréal.

van Norden, Simon (2010), "Current trends in the analysis of Canadian productivity growth", North American Journal of Economics and Finance [forthcoming].

Woodford, Michael (2003), Interest $\&$ Prices. Foundations of a Theory of Monetary Policy, Princeton University Press, Princeton, NJ. 